\title{
Modulation of MCP-1, TGF- $\beta 1$, and $\alpha-S M A$ Expressions in Granulation Tissue of Cutaneous Wounds Treated with Local Vitamin B Complex: An Experimental Study
}

\author{
Carla P. Martinelli-Kläy a, d Laurelucia O. Lunardib \\ Celso Ricardo Martinellic ${ }^{c}$ Tommaso Lombardi ${ }^{d}$ Edson G. Soares ${ }^{a}$ \\ Celso Martinellic \\ ${ }^{a}$ Department of Pathology, School of Medicine of Ribeirão Preto, and ${ }^{b}$ Department of \\ Morphology, Stomatology and Physiology, School of Dentistry of Ribeirão Preto, University \\ of São Paulo, and ${ }^{\mathrm{C} C e n t r e ~ f o r ~ D i a g n o s i s ~ a n d ~ T r e a t m e n t ~ o f ~ O r a l ~ D i s e a s e s, ~ R i b e i r a ̃ o ~ P r e t o, ~}$ \\ Brazil; ${ }^{d}$ Oral Medicine and Oral Maxillofacial Pathology Unit, Division of Oral Maxillofacial \\ Surgery, Department of Surgery, Geneva University Hospitals and Faculty of Geneva, \\ Geneva, Switzerland
}

Key Words

Granulation tissue $\cdot$ Vitamin B complex $\cdot$ TGF- $\beta 1 \cdot \mathrm{MCP}-1 \cdot \alpha-\mathrm{SMA}$

\begin{abstract}
Vitamin B complex can modulate the inflammatory response and activate wound healing. However, the action mechanisms involved in this process are still unclear. The aim of this study was to evaluate the effects of vitamin $B$ complex on the modulation of monocyte chemotactic protein (MCP)-1, transforming growth factor (TGF)- $\beta 1$, and $\alpha$-smooth muscle actin ( $\alpha$-SMA) in granulation tissue growth. Cutaneous ulcers on Wistar rats were topically treated with vitamin B complex. MCP-1, TGF- $\beta 1$, and $\alpha$-SMA expressions were evaluated 24, 72, and $168 \mathrm{~h}$ after the treatment. Inflammatory cells were counted and collagen fibril staining was performed. After 24 h, more mononuclear cells $(p \leq 0.01)$ and a higher MCP-1 ( $\leq \leq 0.05)$ and TGF- $\beta 1$ ( $p \leq 0.01$ ) expression were observed. After $72 \mathrm{~h}$, the number of fibroblasts and mononuclear cells ( $p \leq 0.05$ ) was elevated. After $168 \mathrm{~h}$, an increased number of fibroblasts, myofibroblasts, and blood vessels $(p \leq 0.01)$ as well as a strong intensity of collagen fibril staining were seen. At that point, the cells presented a higher TGF- $\beta 1$ expression $(p \leq 0.05)$, and the size of the ulcer area was decreased $(p \leq 0.01)$. We can conclude that vitamin $B$ complex may stimulate a positive modulation of MCP-1, TGF- $\beta 1$, and $\alpha$-SMA expressions in granulation tissue of cutaneous ulcers.




\section{Introduction}

Cutaneous wound healing is a dynamic process involving 3 stages: (1) inflammation, (2) new tissue formation (e.g. fibroplasia, neovascularization, or re-epithelialization), and (3) tissue reorganization or remodeling of the extracellular matrix [1, 2]. After an injury, the damaged blood vessels, degranulated platelets, and parenchymal cells secrete several mediators of wound healing including transforming growth factor (TGF)- $\beta$ and monocyte chemotactic protein (MCP)-1. These substances do not only recruit inflammatory leukocytes (e.g. neutrophils or monocytes/macrophages) to the injury site, but they also contribute to the formation of granulation tissue and the contraction of the wound. The granulation tissue which is responsible for wound healing consists of new blood vessels, fibroblasts, inflammatory cells, myofibroblasts, and a provisional extracellular matrix [1, $2]$. With different stimuli (e.g. TGF- $\beta$ or mechanical tension), fibroblasts can express $\alpha$-smooth muscle actin ( $\alpha$-SMA) and form myofibroblasts with a contraction capacity [2-4].

Vitamins, which are considered dietary substances required for a normal cellular metabolism, act as coenzymes and can also be significant in wound healing [5]. For example, the vitamins of the B complex group may modulate inflammation [6-8] and activate healing [9-20]. Furthermore, in cases of acute pain, the addition of B vitamins to diclofenac can increase its analgesic effect [21]. However, the action mechanisms of vitamin B complex in cutaneous wound healing still remain unclear. In the present study, we investigated the role of vitamin B complex in the modulation of MCP-1, TGF- $\beta 1$, and $\alpha$-SMA expressions in granulation tissue of cutaneous wounds.

\section{Materials and Methods}

Thirty male Wistar rats ( 56 days old) were divided into 2 groups. The rats $(n=15)$ in the control group received no treatment. In the experimental group, the wounds of the rats $(\mathrm{n}=$ 15) were treated with vitamin B complex. This study was approved by the Ethics Committee for Animal Usage (CEUA) of the University of São Paulo - USP, Brazil (protocol No. 04.1.700.53.9).

After injecting an intramuscular general anesthesia using $0.75 \mathrm{ml}$ compazine and 0.038 ml ketamine, the rats' dorsal regions were depilated. A skin excision of $6 \times 6 \mathrm{~mm}$ was performed on the rats' subscapular regions using a punch instrument that contained a stop resin at $2 \mathrm{~mm}$ depth. In the experimental group, the rats' ulcers were topically treated with a single dose of vitamin B complex (5 mg vitamin B1, 2 mg vitamin B2, 3 mg vitamin B5, 2 mg vitamin B6, 20 $\mathrm{mg}$ nicotinamide, and $0.25 \mathrm{mg}$ biotin; Bayer). The size of the wound was measured daily. The ulcer area and the percentage of contraction were then calculated. The composition and the concentration of vitamin B complex were analyzed using high-performance liquid chromatography.

At 24, 72, and $168 \mathrm{~h}$ after the treatment, skin samples were harvested and fixed in $4 \%$ paraformaldehyde. The samples were cut into $4-\mu \mathrm{m}$-thick sections and stained with hematoxylin and eosin and Masson trichrome. Immunohistochemical techniques were used for the analysis of MCP-1, TGF- $\beta 1$, and $\alpha$-SMA expression.

\section{Immunohistochemistry}

Histological sections were placed on organosilane-pretreated slides, deparaffinized with xylene, rehydrated, and incubated with 3\% hydrogen peroxide for 5 min to block endogenous peroxidase activity. For different cells quantification, the slides were incubated with primary 

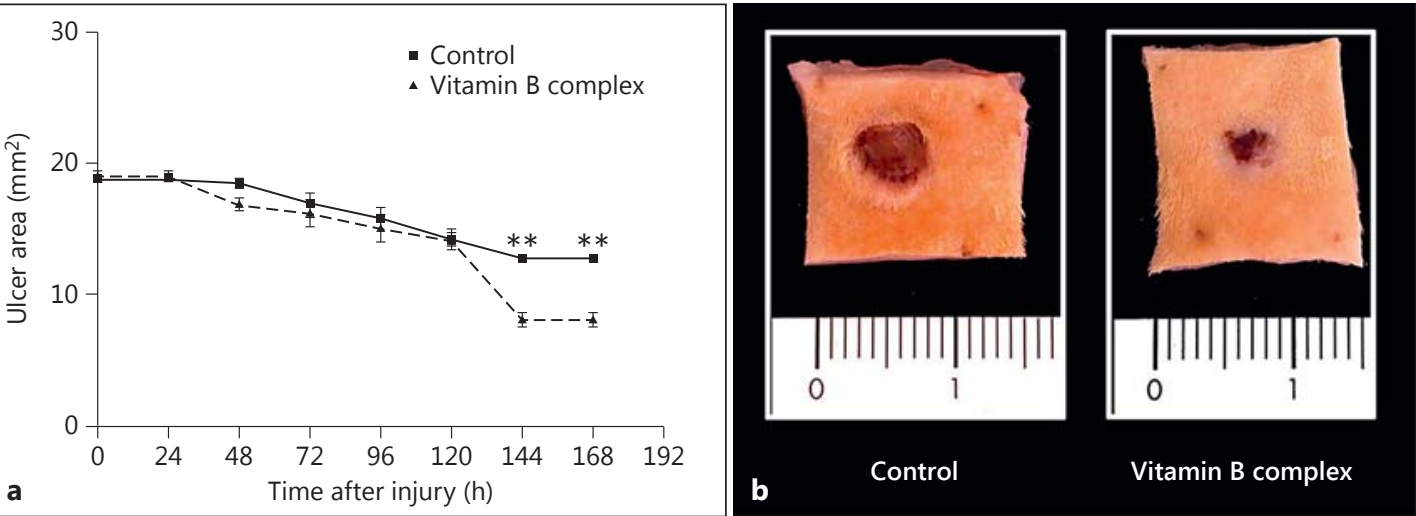

Fig. 1. a Wound area analysis at different points in time. b Clinical aspects of the cutaneous ulcers at $168 \mathrm{~h}$ after the injury. ${ }^{* *} \mathrm{p} \leq 0.01$.

antibodies for $2 \mathrm{~h}$ : monoclonal mouse anti-human $\alpha$-SMA antibody (1A4 clone, code M0851, 1:250 dilution, Dako), polyclonal goat anti-rat MCP-1 antibody (code R17, 1:100 dilution, Santa Cruz Biotechnology Inc.), or polyclonal goat anti-human TGF- $\beta 1$ antibody (code 6G, 1:300 dilution, Santa Cruz Biotechnology Inc.). Subsequently, the sections were incubated with a second biotin antibody (Universal Kit, Novocastra Laboratories Ltd.) for $15 \mathrm{~min}$. Then, the histological sections were developed using 3,3'-diaminobenzidine (Sigma Chemical Co.) as a chromogen and light counterstaining with Meyer hematoxylin. The slides were dehydrated in graded alcohol, cleared in xylene, and mounted in Permount (Merck, Darmstadt, Germany). We also prepared negative controls, omitting the primary antibody from the assay and replacing it with nonimmune goat serum for MCP- 1 and TGF- $\beta 1$ and nonimmune mouse serum for $\alpha$-SMA.

\section{Cellular Quantification}

The quantity of cells was evaluated histologically in tissues stained with hematoxylin and eosin. The blood vessels were quantified using the immunohistochemical staining for $\alpha$-SMA. Six random microscopic fields per wound ( 2 fields at the base and 2 fields on each edge) were selected using a microscope with a 20-point ocular graticule (catalog No. 474004, Zeiss) with $\times 400$ magnification, covering a total of $0.345 \mathrm{~mm}^{2}$ per wound.

\section{Statistical Analysis}

The analysis of variance, followed by a Bonferroni test, was applied in order to quantitatively compare the presence of different cells as well as the immunohistochemical expression of TGF- $\beta 1$, MCP- 1 , and $\alpha$-SMA at different times and for different treatments. A probability of $\leq 0.05$ was considered significant.

\section{Results}

\section{Clinical Analysis}

A decrease in the size of the wounded area could be observed after $120 \mathrm{~h}$ (day 5; fig. 1a). Those ulcers that had been treated with local vitamin B complex presented significantly higher contractions ( $\mathrm{p} \leq 0.01$ ) 144 and $168 \mathrm{~h}$ after the injury (55 and 58\%, respectively) 


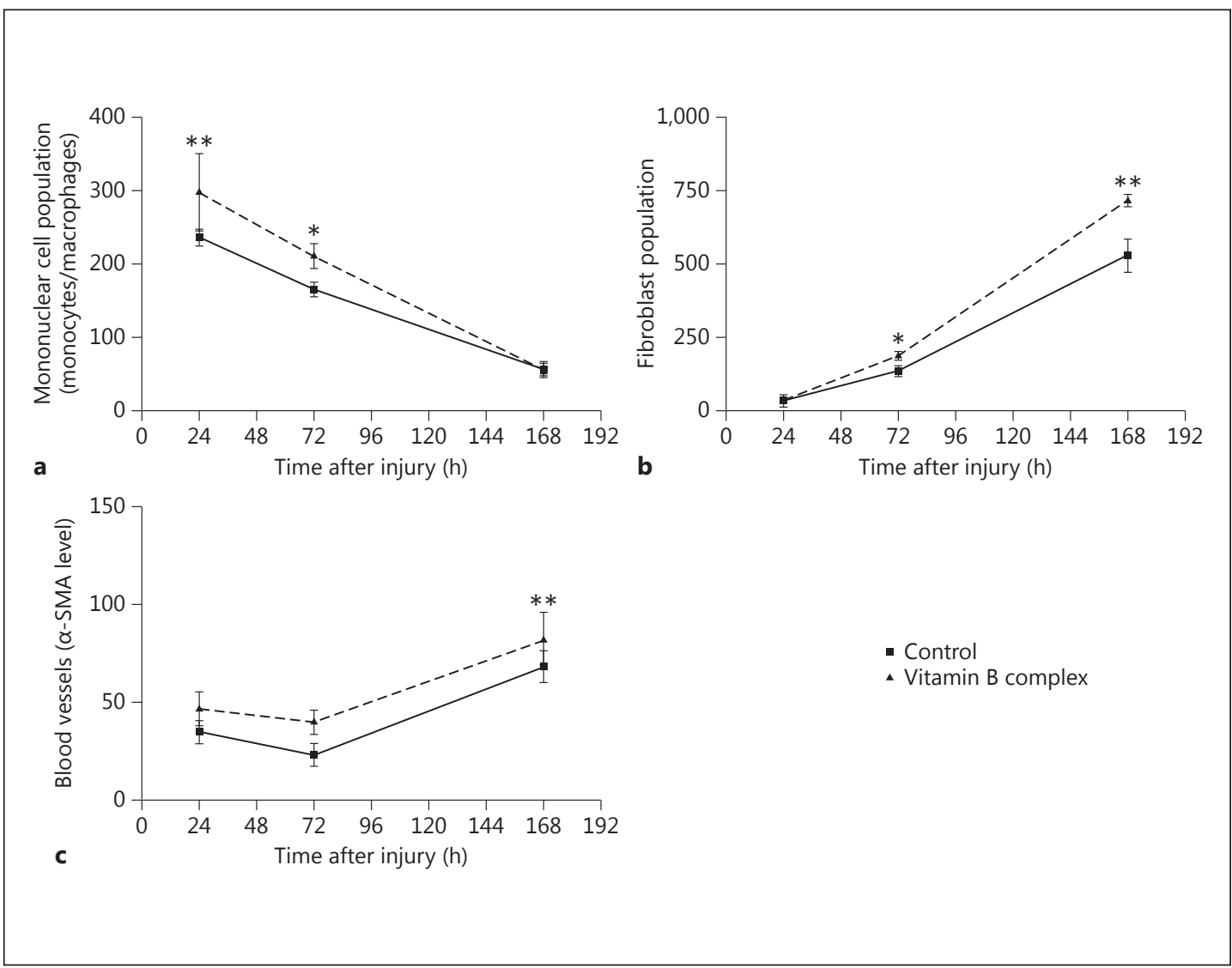

Fig. 2. Quantification of mononuclear cells (monocytes/macrophages; a), fibroblasts (b), and blood vessels (c) using hematoxylin and eosin staining $(\mathbf{a}, \mathbf{b})$ or immunohistochemical staining for $\alpha$-SMA (c). * $\mathrm{p} \leq 0.05$; $* * \mathrm{p} \leq 0.01$.

when compared to the ulcers of the control group, which decreased only by 30 and $32.1 \%$, respectively (fig. 1a). The clinical aspects of wound contractions are shown in figure $1 \mathrm{~b}$ for samples taken $168 \mathrm{~h}$ after the injury.

\section{Histological Analysis}

At $24 \mathrm{~h}$ after the injury, although the skin wounds of both the control group and the experimental group had filled with fibrin and showed a dehydrated crust on the surface, the rats in the experimental group presented less edema and fewer neutrophils (data not shown) as well as a statistically larger mononuclear inflammatory cell population (monocytes/ macrophages; $\mathrm{p} \leq 0.01$; fig. $2 \mathrm{a}$ ) mainly in the middle and deep regions. Moreover, $72 \mathrm{~h}$ after the injury, those ulcers treated with local vitamin B complex presented more fibroblasts ( $\mathrm{p} \leq$ 0.05 ; fig. $2 \mathrm{~b}$ ) and mononuclear cells (monocytes/macrophages; $\mathrm{p} \leq 0.05$; fig. $2 \mathrm{a}$ ) than the ulcers from the control group. At $168 \mathrm{~h}$ after the injury, the ulcers of both groups (control and experimental) were filled with granulation tissue (fig. 3a, b). However, the numbers of fibroblasts ( $\mathrm{p} \leq 0.01$; fig. $2 \mathrm{~b}$ ) and blood vessels ( $\mathrm{p} \leq 0.01$; fig. $2 \mathrm{c}$ ) were significantly higher in the experimental group than in the control group. In addition, more collagenization was observed in the experimental group with Masson trichrome stain mainly in the middle and deep regions (fig. 3c, d). 

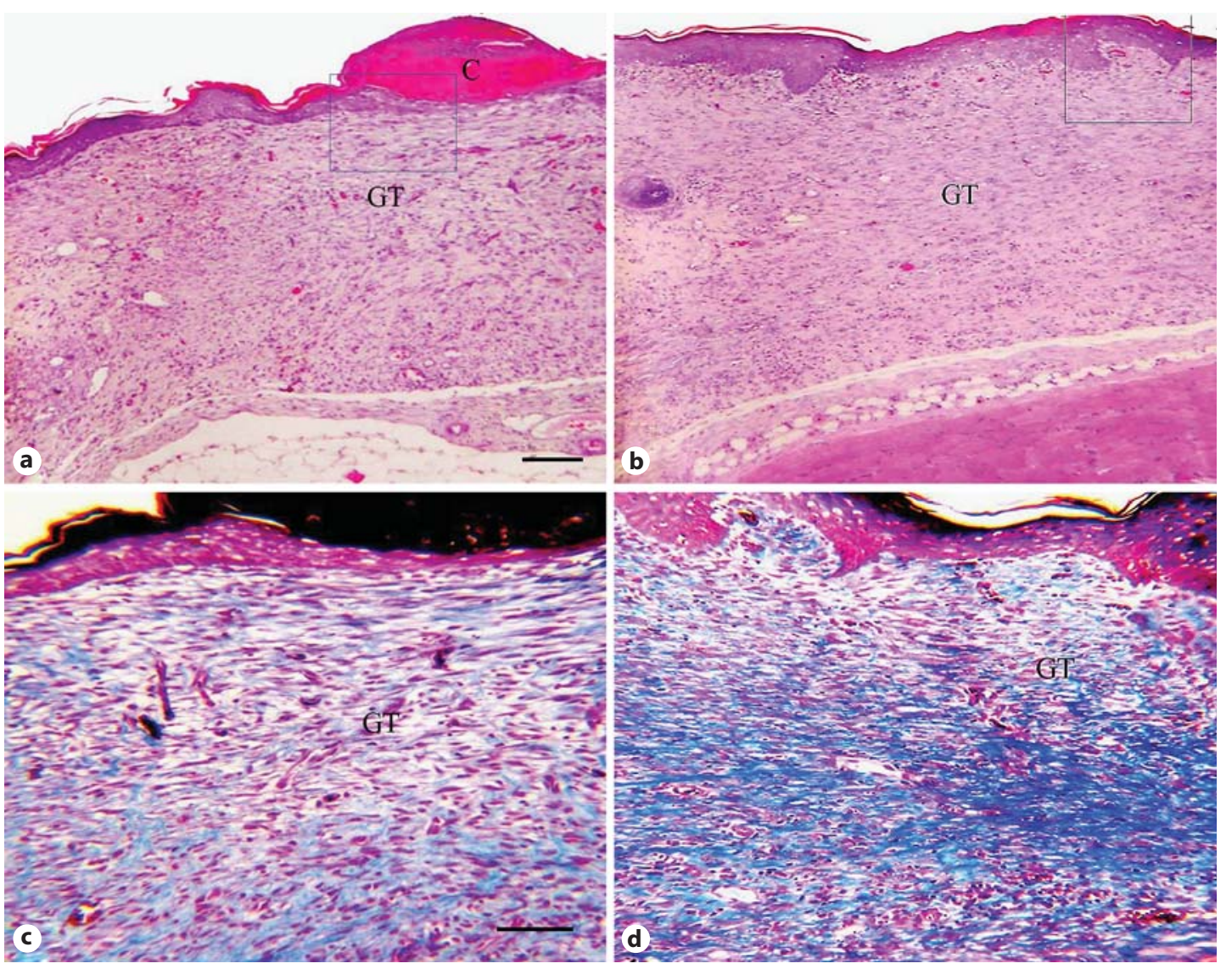

Fig. 3. Histological analysis of the cutaneous ulcers stained with hematoxylin and eosin (a, b) and Masson's trichrome (c, d) at $168 \mathrm{~h}$ after the injury. The experimental group (b, d) presented a more developed granulation tissue showing more collagenization on Masson's trichrome stain mainly in the middle and deep regions when compared to the control group $(\mathbf{a}, \mathbf{c})$. C = Crust; GT = granulation tissue. Scale bar = $1 \mathrm{~mm}(\mathbf{a}, \mathbf{b})$; scale bar $=0.1 \mathrm{~mm}(\mathbf{c}, \mathbf{d})$.

\section{Immunohistochemical Analysis}

Analysis of MCP-1 Expression

At $24 \mathrm{~h}$ after the injury, MCP-1 was predominantly expressed in mononuclear inflammatory cells (monocytes/macrophages), fibroblasts, and endothelial cells (fig. 4b) in both groups. The peak in MCP-1 expression occurred $24 \mathrm{~h}$ after the injury; however, it was significantly higher in the experimental group than in the control group ( $\mathrm{p} \leq 0.05$; fig. $4 \mathrm{a}$ ).

\section{Analysis of TGF- $\beta 1$ Expression}

At $24 \mathrm{~h}$ after the injury, TGF- $\beta 1$ expression was mainly verified in mononuclear inflammatory cells (monocytes/macrophages), fibroblasts, and endothelial cells in both the control and the experimental group (fig. $4 \mathrm{~d}$ ). In contrast to the control group, which presented a constant TGF- $\beta 1$ expression at all times (after 24,72 , and $168 \mathrm{~h}$ ), the ulcers of the rats treated with vitamin B complex presented two peaks in TGF- $\beta 1$ expression. One of these peaks took place $24 \mathrm{~h}$ after the treatment, whereas the other peak occurred $168 \mathrm{~h}$ after the treatment. At both points in time, the TGF- $\beta 1$ expression in the experimental group was significantly higher $(24 \mathrm{~h}, \mathrm{p} \leq 0.01 ; 168 \mathrm{~h}, \mathrm{p} \leq 0.05)$ than that in the control group (fig. 4c). At $168 \mathrm{~h}$ after the injury, TGF- $\beta 1$ was also expressed in epithelial cells (data not shown). 

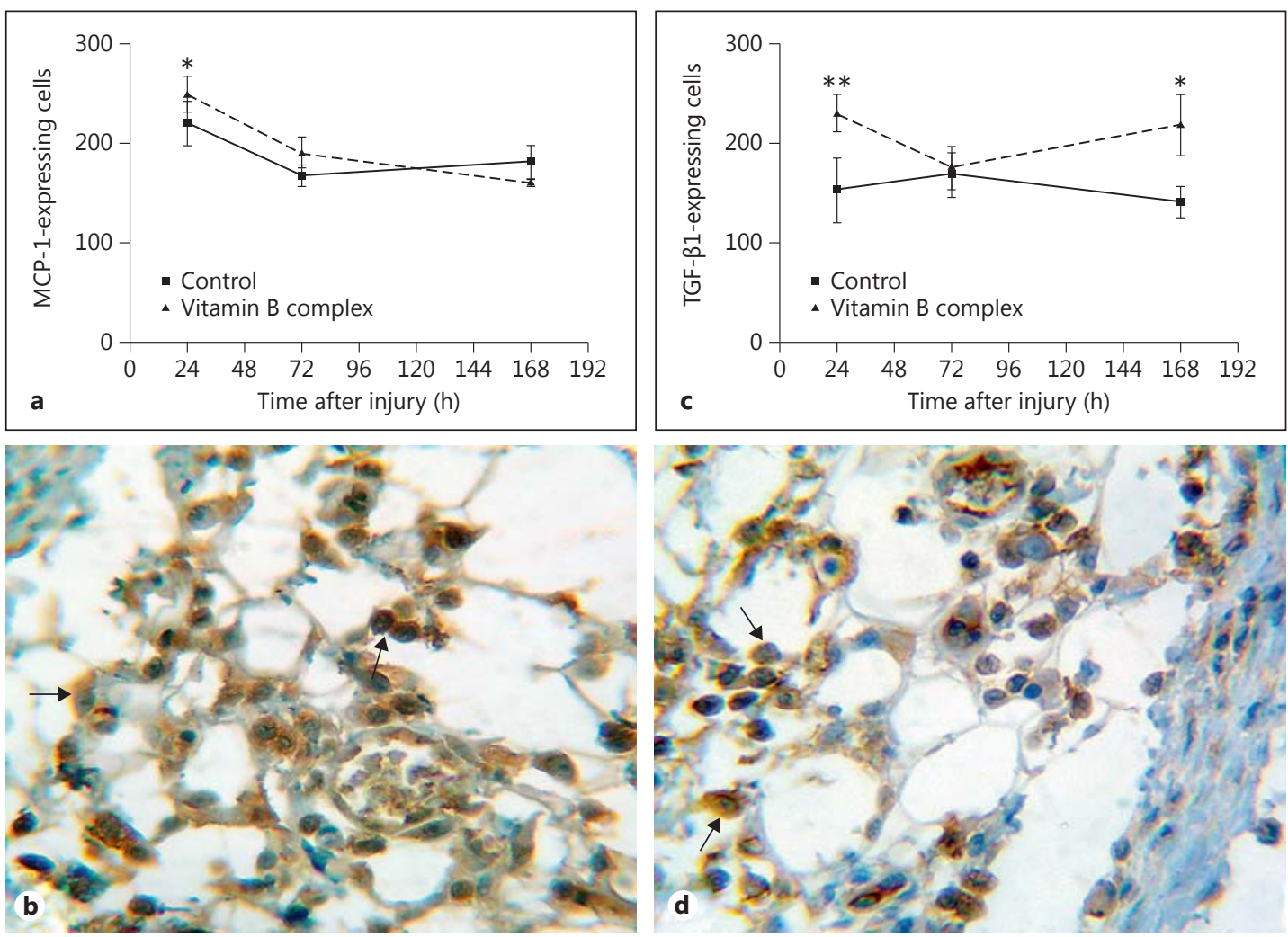

Fig. 4. Quantification of MCP-1- (a) and TGF- $\beta 1$-expressing cells (c) at 24,72 and $168 \mathrm{~h}$ after the injury. MCP1 and TGF- $\beta 1$ (arrows) were mainly expressed in mononuclear inflammatory cells (monocytes/macrophages), fibroblasts, and endothelial cells. Both MCP-1 and TGF- $\beta 1$ expressed a cytoplasm staining (b, d). Scale bar $=0.1 \mathrm{~mm} .{ }^{*} \mathrm{p} \leq 0.05 ;^{* *} \mathrm{p} \leq 0.01$.

Myofibroblast Analysis

Myofibroblasts were only observed $168 \mathrm{~h}$ after the injury (fig. 5a). After 24 and $72 \mathrm{~h}$, smooth muscle cells and cells in the pericyte stained for $\alpha$-SMA (data not shown). At $168 \mathrm{~h}$ after the injury, the wounds treated with local vitamin B complex presented a significantly higher expression of $\alpha$-SMA when compared to the control ulcers ( $\mathrm{p} \leq 0.01$; fig. 5). The degree of wound contractions was correlated with an increase in contractile myofibroblasts expressing $\alpha$-SMA (fig. 1,5 ).

\section{Discussion}

Although many studies are available in the literature, an effective treatment of cutaneous wounds has not been clearly defined yet. According to the literature, vitamin B complex can modulate inflammation [6-8] and activate the healing process [9-20]. However, the mechanisms through which they act remain unclear. Our results are in agreement with the literature. Those ulcers treated with local vitamin B complex presented not only a significantly higher degree of contraction $168 \mathrm{~h}$ after the injury (fig. 1a, b), but also a larger fibroblast and vascular population at 72 and $168 \mathrm{~h}$ after the injury (fig. 2b, c). At $168 \mathrm{~h}$ after the treatment, those ulcers treated with local vitamin B complex showed a higher intensity for collagen fibril staining, suggesting a greater maturation of the granulation tissue (fig. 3c, d). 

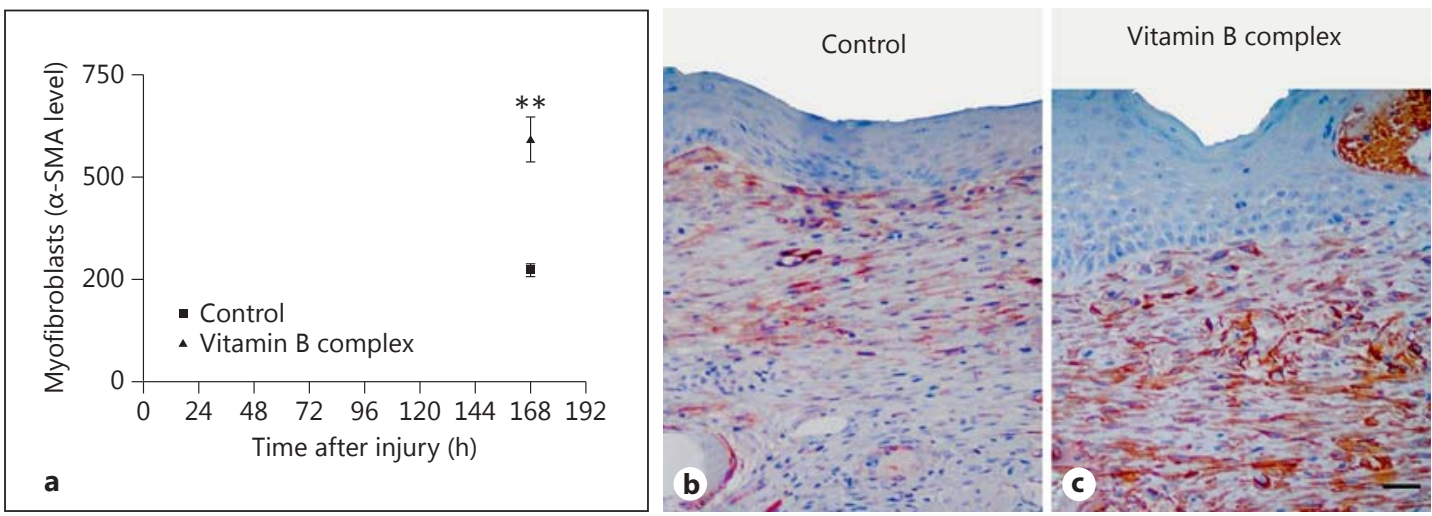

Fig. 5. a Quantification of $\alpha$-SMA-expressing cells. b, c Histological features of $\alpha$-SMA-expressing cells are mainly observed in myofibroblasts. Scale bar $=0.34 \mathrm{~mm} .{ }^{* *} \mathrm{p} \leq 0.01$.

Vitamin B can increase the lysyl-oxidase activity - the essential enzyme in the formation of collagen $[9,12]$. The topical use of dexpanthenol, the stable alcoholic form of pantothenic acid (vitamin B5), is widely used in skin care and in the treatment of various dermatological diseases. It stimulates the regeneration and promotes the wound healing of the skin [22-24]. An upregulation of IL-6, IL-1 $\beta$, CYP1B1, CXCL1, CCL8, and KAP gene expressions by vitamin B5 has been shown [24]. Biotin or vitamin B complex supplementation clinically improved the wound healing of uncomplicated sole ulcers in animals [17] or of periodontal tissue after surgery [19], respectively. Furthermore, folate supplementation stimulated DNA synthesis in the wounds of rabbits [20] as well as reduced the level of plasma homocysteine, a sulfhydrylcontaining amino acid involved in the bioavailability of nitric oxide [25, 26]. According to de Lucia and Martinelli [14], fibrin is more rapidly substituted by granulation tissue in the alveoli of vitamin B6-supplemented rats when compared to a control group. Dexpanthenol also downregulated psoriasin (S100 calcium-binding protein A7A) mRNA and protein expressions [24]. Psoriasin is markedly increased in epidermal hyperproliferative disorders, in wound exudates, in parts of the epidermis surrounding acute wounds, and in the margins of nonhealing chronic leg ulcers [27].

Diverse chemokines have been suggested to play an important role in the healing process. One of these substance is MCP-1, a member of the CC family of chemokines (or $\beta$-chemokines), expressed in different kinds of cells (e.g. keratinocytes, fibroblasts, monocytes/macrophages, or endothelial cells). MCP-1, which binds to CC chemokine receptor 2, is able to stimulate the migration of monocytes/macrophages and endothelial cells; additionally, it can activate the production of the extracellular matrix [28-30]. It has also been shown that MCP-1 is related to TGF- $\beta 1$ expression [31]. MCP-1 can mediate the angiogenic effect of TGF- $\beta$ through the activation of vascular smooth muscle cell and mesenchymal cell migration toward endothelial cells $[32,33]$. Our study showed that the MCP-1 expression was significantly higher in the experimental group than in the control group $24 \mathrm{~h}$ after the treatment (fig. $4 \mathrm{a}$ ). In addition, there was a significantly larger population of mononuclear inflammatory cells (monocytes/ macrophages) in the experimental group 24 and $72 \mathrm{~h}$ after the treatment (fig. 2a). According to the literature, the highest level of MCP-1 or its mRNA occurs during the initial phase of the healing process (after $24 \mathrm{~h}$ ), and it diminishes during the following periods [33, 34]. Nevertheless, some researches on mice showed that the migration of monocytes/macrophages is not strictly related to the chemokine MCP-1 [30-34], but its inhibition decreased the angiogenesis and synthesis of collagen in mouse ulcers [29]. 
Another essential chemokine involved in wound healing is TGF- $\beta 1$. This chemokine is considered to be a member of the superfamily of polypeptides, where 3 out of 5 isoforms are produced by mammalian cells (TGF- $\beta 1$, TGF- $\beta 2$, and TGF- $\beta 3$ ). This growth factor, which is produced by most cells, acts through serine/threonine kinase. TGF- $\beta 1$ is able to activate the angiogenesis, fibroblastic proliferation, and production of collagenous fibers $[35,36]$ and macrophage migration [37,38]. According to Mustoe et al. [37], only one application of TGF- $\beta 1$ to an ear ulcer in a rabbit is sufficient to accelerate the formation of granulation tissue. In our study, TGF- $\beta 1$ was significantly more expressed in ulcers topically treated with a single dose of vitamin B complex when compared to the control group 24 and $168 \mathrm{~h}$ after the treatment (fig. 4c).

It has also been suggested that TGF- $\beta 1$ in association with another substance/event (e.g. specialized ECM proteins, like the ED-A splice variant of fibronectin, and high extracellular stress) is able to activate the formation of $\alpha$-SMA-positive myofibroblasts [3, 39, 40]. Binding of TGF- $\beta$ to the receptor leads to the phosphorylation of the cytoplasmic proteins called Smads, which enter the nucleus and can regulate $\alpha$-SMA transcription together with other transcription factors $[35,36]$. TGF- $\beta$ can also accelerate the differentiation of fibrocytes into mature fibroblasts and myofibroblasts [4, 41, 42]. Different cell types such as fibrocytes, resident fibroblasts, smooth muscle cells, pericytes, and mesenchymal stromal cells have been considered as the origin of myofibroblast progenitors $[2,43]$. When activated, myofibroblasts are able to contract wounded skin [40]. Furthermore, myofibroblasts can express collagen types I, III, IV, V, and VI, glycoproteins, and proteoglycans (e.g. fibronectin, laminin, or tenascin) [43]. According to our results, ulcers treated with local vitamin B complex did not only show significantly larger myofibroblast populations $168 \mathrm{~h}$ after the treatment (fig. 5), but also a higher contraction of the cutaneous ulcers (58.28\%) when compared to the control group (32.1\%; fig. 1).

It has been shown that there are two peaks of active TGF- $\beta$ in the healing process. One of the peaks occurs at the initial phase of wound healing, whereas a second peak coincides with the appearance of myofibroblasts. Co-cultures of keratinocytes and fibroblasts showed high levels of active TGF- $\beta$ protein after 24 and $48 \mathrm{~h}$, whereas the differentiation into myofibroblasts started after 4 days or later [44]. According to Cheon et al. [45], the increase in growth factor during the initial phase is able to activate $\beta$-catenin in fibroblasts of mice in the experimental model in vitro or in vivo. $\beta$-Catenin may mediate the effect of TGF- $\beta$ and regulate the wound size in cutaneous healing [46]. In addition, this protein together with nuclear protein family TCF-LEF activates the expression of genes in the late phase, e.g. metalloproteinase [45]. Our results suggest that one local application of vitamin B complex can activate the formation of granulation tissue and its maturation as well as the development of myofibroblasts and wound closure, probably through the increase of TGF- $\beta$ and MCP-1 expression.

\section{Acknowledgements}

The authors greatly thank the technician Ana Maria da Rocha.

\section{Disclosure Statement}

There are no competing conflicts of interest. 
Martinelli-Kläy et al.: Vitamin B Complex and MCP-1, TGF- $\beta 1$, and $\alpha$-SMA Expressions

\section{References}

1 Behm B, Babilas P, Landthaler M, Schreml S: Cytokines, chemokines and growth factors in wound healing. I Eur Acad Dermatol Venereol 2012;26:812-820.

-2 Greaves NS, Ashcroft KJ, Baguneid M, Bayat A: Current understanding of molecular and cellular mechanisms in fibroplasia and angiogenesis during acute wound healing. J Dermatol Sci 2013;72:206-217.

-3 Hinz B, Phan SH, Thannickal VJ, Prunotto M, Desmoulière A, Varga J, De Wever O, Mareel M, Gabbiani G: Recent developments in myofibroblast biology: paradigms for connective tissue remodeling. Am J Pathol 2012;180: 1340-1355.

4 Bucala R: Review Series - Inflammation \& Fibrosis: Fibrocytes and fibrosis. QJM 2012;105:505-508.

5 MacKay D, Miller AL: Nutritional support for wound healing. Altern Med Rev 2003;8:359-377.

6 Jonas WB, Rapoza CP, Blair WF: The effect of niacinamide on osteoarthritis: a pilot study. Inflamm Res 1996; 45:330-334.

7 Pero RW, Axelsson B, Siemann D, Chaplin D, Dougherty G: Newly discovered anti-inflammatory properties of the benzamides and nicotinamides. Mol Cell Biochem 1999;193:119-125.

8 Ebnener F, Heller A, Rippke F, Tausch I: Topical use of dexpanthenol in skin disorders. Am J Clin Dermatol 2002;3:427-433.

-9 Murray JC, Levene CI: Evidence for the role of vitamin C-6 as a cofactor of lysyl oxidase. Biochem J 1977;167: 463-467.

10 Pack AR: Folate mouthwash: effects on established gingivits in periodontal patients. J Clin Periodontol 1984; 11:619-628.

11 Pack AR: Effects of folate mouthwash on experimental gingivits in man. J Clin Periodontol 1986;13:671-676.

12 Alvarez OM, Gilbreath RL: Effect of dietary thiamine on intermolecular collagen cross-linking during wound repair: a mechanical and biochemical assessment. J Trauma 1982;22:20-24.

13 Lacroix B, Didier E, Grenier JF: Role of pantothenic and ascorbic acid in wound healing processes: in vitro study on fibroblasts. Int J Vitam Nutr Res 1988;58:407-413.

14 de Lucia MB, Martinelli C: Tooth extraction wound healing after administration of vitamin B6 (pyridoxine). Histological study in rats (in Portuguese). Arq Cent Estud Curso Odontol 1989;25-26:28-34.

15 Vaxman F, Olender S, Lambert A, Nisand G, Grenier JF: Can the wound healing process be improved by vitamin supplementation? Experimental study on humans. Eur Surg Res 1996;28:306-309.

-16 Weimann BI, Hermann D: Studies on wound healing: effects of calcium D-pantothenate on the migration, proliferation and protein synthesis of human dermal fibroblasts in culture. Int J Vitam Nutr Res 1999;69: 113-119.

17 Lischer CHJ, Koller U, Geyer H, Mulling CH, Schulze J, Ossent P: Effect of therapeutic dietary biotin on the healing of uncomplicated sole ulcers in dairy cattle - a double blinded controlled study. Vet J 2002;163:51-60.

-18 Neiva RF, Steigenga J, Al-Shammari KF, Wang HL: Effects of specific nutrients on periodontal disease onset, progression and treatment. J Clin Periodontol 2003;30:579-589.

19 Neiva RF, Al-Shammari K, Nociti FH, Soehren S, Wang HL: Effects of vitamin-B complex supplementation on periondontal wound healing. J Periodontol 2005;76:1084-1091.

20 Zhang XJ, Chinkes DL, Herndon DN: Folate stimulation of wound DNA synthesis. J Surg Res 2008;147:15-22.

-21 Ponce-Monter HA, Ortiz MI, Garza-Hernández AF, Monroy-Maya R, Soto-Ríos M, Carrillo-Alarcón L, ReyesGarcía G, Fernández-Martínez E: Effect of diclofenac with B vitamins on the treatment of acute pain originated by lower-limb fracture and surgery. Pain Res Treat 2012;2012:104782.

-22 Proksch E, Nissen HP: Dexpanthenol enhances skin barrier repair and reduces inflammation after sodium lauryl sulphate-induced irritation. J Dermatolog Treat 2002;13:173-178.

23 Dell'Acqua G, Schweikert K: Panthenyl triacetate transformation, stimulation of metabolic pathways, and wound-healing properties in the human skin. J Cosmet Sci 2012;63:1-13.

-24 Heise R, Skazik C, Marquardt Y, Czaja K, Sebastian K, Kurschat P, Gan L, Denecke B, Ekanayake-Bohlig S, Wilhelm KP, Merk HF, Baron JM: Dexpanthenol modulates gene expression in skin wound healing in vivo. Skin Pharmacol Physiol 2012;25:241-248.

-25 Bagheri M, Jahromi BM, Zamani A: Folic acid may be a potential addition to diabetic foot ulcer treatment - a hypothesis. Int Wound J 2011;8:658-660.

-26 Forges T, Monnier-Barbarino P, Alberto JM, Guéant-Rodriguez RM, Daval JL, Guéant JL: Impact of folate and homocysteine metabolism on human reproductive health. Hum Reprod Update 2007;13:225-238.

27 Eckert RL, Lee KC: S100A7 (Psoriasin): a story of mice and men. J Invest Dermatol 2006;126:1442-1444.

28 Dipietro LA, Reintjes MG, Low QE, Levi B, Gamelli RL: Modulation of macrophage recruitment into wound by monocyte chemoattractant protein-1. Wound Repair Regen 2001;9:28-33.

-29 Gruss CJ, Satyamoorthy K, Berking C, Lininger J, Nesbit M, Schaider H, Liu ZJ, Oka M, Hsu MY, Shirakawa T, Li G, Bogenrieder T, Carmeliet P, El-Deiry WS, Eck SL, Rao JS, Baker AH, Bennet JT, Crombleholme TM, Velazquez O, Karmacharya J, Margolis DJ, Wilson JM, Detmar M, Skobe M, Robbins PD, Buck C, Herlyn M: Stroma formation and angiogenesis by overexpression of growth factors, cytokines, and proteolytic enzymes in human skin grafted to SCID mice. J Invest Dermatol 2003;120:683-692.

-30 Low QE, Drugea IA, Duffner LA, Quinn DG, Cook DN, Rollins BJ, Kovacs EJ, Dipietro LA: Wound healing in MIPalpha ${ }^{-/-}$and MCP-1/-- mice. Am J Pathol 2001;159:457-463. 
-31 Gharaee-Kermani M, Denholm EM, Phan SH: Costimulation of fibroblast collagen and transforming growth factor $\beta 1$ gene expression by monocyte chemoattractant protein-1 via specific receptor. J Biol Chem 1996;271: 17779-17784.

32 Ma J, Wang Q, Fei T, Han JDJ, Chen YG: MCP-1 mediates TGF- $\beta$-induced angiogenesis by stimulating vascular smooth muscle cell migration. Blood 2007;109:987-994.

-33 Engelhardt E, Toksoy A, Goebeler M, Debus S, Brocker EB, Gillitzer R: Chemokines IL-8, GROalpha, MCP-1, IP-10, and Mig are sequentially and differentially expressed during phase-specific infiltration of leukocyte subsets in human wound healing. Am J Pathol 1998;153:1849-1860.

34 Jackman SH, Yoak MB, Keerthy S, Beaver BL: Differential expression of chemokines in mouse model of wound healing. Ann Clin Lab Sci 2000;30:201-207.

-35 Finnson KW, McLean S, Di Guglielmo GM, Philip A: Dynamics of transforming growth factor beta signaling in wound healing and scarring. Adv Wound Care (New Rochelle) 2013;2:195-214.

-36 Pakyari M, Farrokhi A, Maharlooei MK, Ghahary A: Critical role of transforming growth factor beta in different phases of wound healing. Adv Wound Care (New Rochelle) 2013;2:215-224.

37 Mustoe TA, Pierce GF, Morishima C, Deuel TE: Growth factor-induced acceleration of tissue repair through direct and inductive activities in a rabbit dermal ulcer model. J Clin Invest 1991;87:694-703.

38 Puolakkainen PA, Reed MJ, Gombotz WR, Twardzik DR, Abrass IB, Sage EH: Acceleration of wound healing in aged rats by topical application of transforming growth factor- $\beta 1$. Wound Repair Regen 1995;3:330-339.

-39 Serini G, Bochaton-Piallat ML, Ropraz P, Geinoz A, Borsi L, Zard L, Gabbiani G: The fibronectin domain ED-A is crucial for myofibroblastic phenotype induction by transforming factor-beta1. J Cell Biol 1998;142:873-881.

40 Van De Water L, Varney S, Tomasek JJ: Mechanoregulation of the myofibroblast in wound contraction, scarring, and fibrosis: opportunities for new therapeutic intervention. Adv Wound Care (New Rochelle) 2013;2:122141.

41 Abe R, Donnelly SC, Peng T, Bucala R, Metz CN: Peripheral blood fibrocytes: differentiation pathway and migration to wound sites. J Immunol 2001;166:7556-7562.

42 Schmidt M, Sun G, Stacey MA, Mori L, Mattoli S: Identification of circulating fibrocytes as precursors of bronchial myofibroblasts in asthma. J Immunol 2003;171:380-389.

43 Klingberg F, Hinz B, White ES: The myofibroblast matrix: implications for tissue repair and fibrosis. J Pathol 2013;229:298-309.

44 Yang L, Qui CX, Ludlow A, Ferguson MW, Brunner G: Active transforming growth factor-beta in wound repair: determination using a new assay. Am J Pathol 1999;154:105-111.

-45 Cheon SS, Nadesan P, Poon R, Alman B: Growth factors regulate beta-catenin-mediated TCF-dependent transcriptional activation in fibroblasts during the proliferative phase of wound healing. Exp Cell Res 2004;293: 267-274.

46 Cheon SS, Wei Q, Gurung A, Youn A, Bright T, Poon R, Whetstone H, Guha A, Alman BA: Beta-catenin regulates wound size and mediates the effect of TGF-beta in cutaneous healing. FASEB J 2006;20:692-701. 